\title{
Nonlinear Parameter Analysis of Lateral Resistant Performance of Light Frame Shear Wall
}

\author{
Jie Bai \\ School of Civil Engineering, Guizhou University, Guiyang, 550003, China \\ email: 147954114@qq.com
}

\begin{abstract}
Keywords: Light Frame Shear Wall; Nonlinear Parameter Analysis; Lateral Resistant Performance; Design Suggestion
\end{abstract}

\begin{abstract}
On the basis of previous research, the nonlinear finite element analysis of the light frame shear wall is made with the elastic-plastic behavior of wood and shear failure of connecting part. The nonlinear parametric analysis is carried out for lateral resistant performance of the light frame shear wall. Results of analysis proved that: the main influence factors in lateral resistant performance of the light frame shear wall include studs spacing, height-width ratio of wall, the size and position of the openings. In addition, some design suggestions of light frame shear wall are put forward.
\end{abstract}

\section{Introduction}

Light wood frame construction [1] is the structure force system, which is subjected to the various loads by using standard wood members, and it is in increasingly widespread application in recent years. The superiority of light wood frame construction includes the following aspects: energy-saving thermal insulation, short construction period, cost-effective, better anti-seismic performance and environmental property. The light frame shear wall is the most important load bearing component in light wood frame construction, so mechanical behavior research for light frame shear wall is the basis for a complete theoretical system and design method of light wood frame construction.

Currently, the researches on light frame shear wall mostly focus on static-load tests and dynamical-load tests [2] [3], and the main parameters considered are loading method, cover panel size, connecting parts and opening size [4]. In addition, a lot of researches on the seismic behavior and lateral stiffness of light wood frame construction have been made [5] [6] [7].

On the basis of the previous study, the nonlinear parameter analysis of lateral resistant performance is conducted to the light frame shear wall by the finite element analysis program ABAQUS. In modeling, the elastic-plastic behavior and anisotropic properties of wood, and shear failure of connecting part are considered. Finally, the nonlinear finite element analysis modes of light frame shear wall are established and verified. Through nonlinear parameter analysis for lateral resistant performance, the main effect factors and principle of lateral resistant performance are obtained, and the results will lay a foundation for suggestions to the design method.

\section{Finite Element Models for Light Frame Shear Wall}

As the figure. 1 shows, the finite element model consists of four parts: cover panel element, connecting part element, boundary constraint element and studs element. The element types and material properties are listed in Table.1. The orthogonal two-spring element is used to model the nonlinear slip relationship between the nail and the frame. The nonlinear material behavior of the nail and the wood are also considered in the analysis. 


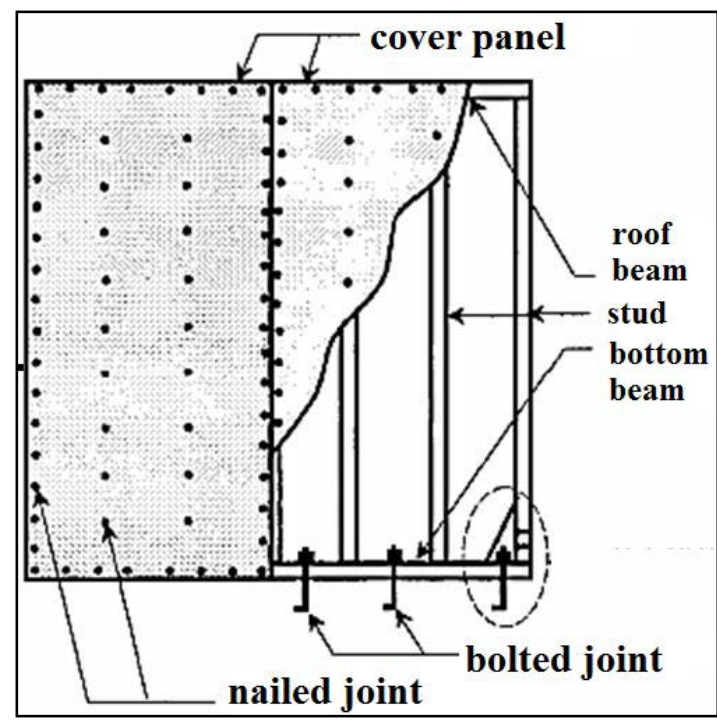

Fig.2. Ultimate lateral stiffness curves

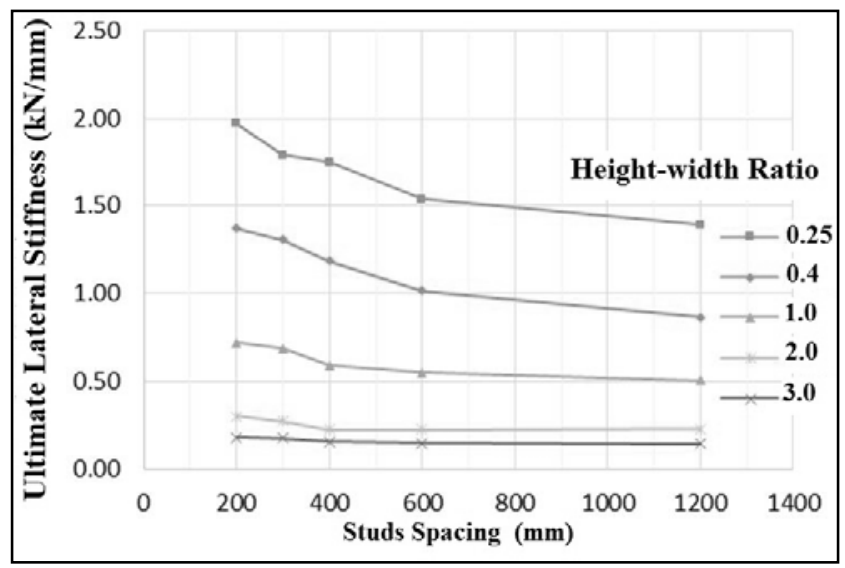

Fig.1. Diagram of light frame shear wall

Table.1 Finite-Element Representation of Structural Components

\begin{tabular}{|c|c|c|}
\hline $\begin{array}{c}\text { Structural } \\
\text { Component }\end{array}$ & $\begin{array}{c}\text { Finite-Element } \\
\text { Representation }\end{array}$ & material property \\
\hline Frame & $\begin{array}{c}\text { Beam element: } \\
\text { 2-node(B21) }\end{array}$ & $\begin{array}{c}\mathrm{E}=9650 \mathrm{MPa} \\
\mathrm{u}=0.3\end{array}$ \\
\hline Cover panel & $\begin{array}{c}\text { Solid element: } \\
\text { 8-node plain stress, }\end{array}$ & $\mathrm{E} 1=1840 \mathrm{MPa}$ \\
& E2=5445MPa \\
& Reduced integration(CPS8R) & $\mathrm{G} 12=620 \mathrm{MPa}$ \\
\hline Nailed joint & Spring element: & $\mathrm{f} 1=3 \mathrm{~N} / \mathrm{mm}, \mathrm{u} 1=0 \mathrm{~mm} ;$ \\
& 2-nodes nonlinear & $\mathrm{f} 2=300 \mathrm{~N} / \mathrm{mm}, \mathrm{u} 2=0.1 \mathrm{~mm} ;$ \\
& (SPRING2) & $\mathrm{f} 3=400 \mathrm{~N} / \mathrm{mm}, \mathrm{u} 3=0.3 \mathrm{~mm} ;$ \\
& Spring element: 2-nodes, & $\mathrm{f} 4=600 \mathrm{~N} / \mathrm{mm}, \mathrm{u} 4=1 \mathrm{~mm} ;$ \\
& linear (SPRING2) & $\mathrm{f} 5=800 \mathrm{~N} / \mathrm{mm}, \mathrm{u} 5=1.7 \mathrm{~mm} ;$ \\
& $\mathrm{f} 6=1000 \mathrm{~N} / \mathrm{mm}, \mathrm{u} 6=4.5 \mathrm{~mm} ;$ \\
& & $\mathrm{f}=1100 \mathrm{~N} / \mathrm{mm}, \mathrm{u} 7=8 \mathrm{~mm} ;$ \\
& $\mathrm{f}=1000 \mathrm{~N} / \mathrm{mm}, \mathrm{u} 8=13.5 \mathrm{~mm} ;$ \\
& $\mathrm{f}=700 \mathrm{~N} / \mathrm{mm}, \mathrm{u} 9=20 \mathrm{~mm}$. \\
\hline
\end{tabular}

\section{Nonlinear Parameter Analysis}

Main parameters include studs spacing, height-width ratio of wall, the size and position of the openings. The relationship of vertical setting of column-and-brace and bearing capacity of the light frame shear wall is studied through non-linear finite analysis, and meanwhile the reasonable setting of brace is discussed.

As the main force component, further researches are needed to probe the effect of studs on lateral resistant performance of light frame shear wall. When height-width ratio of wall keep the same(0.25-3.0), twelve nonlinear finite element models are set up to analysis on lateral behavior of light frame shear wall and confirm the influence of studs spacing, while the studs spacing is transformed (200mm-1200mm).

From the resultant picture.2, we can find that the ultimate lateral stiffness is degraded with the increase of height-width ratio of wall, and becomes more and more flat. In order to reducing the lateral deformation, the height-width ratio of wall should be limit (no more than 1.0). The ultimate lateral stiffness decreases with the increasing of studs spacing within certain range of height-width ratio. Taking the practical situation of engineering application into account, the range of values for 
studs spacing is $400 \mathrm{~mm}$ to $600 \mathrm{~mm}$ when height-width ratio is less than 0.4 , otherwise the range of

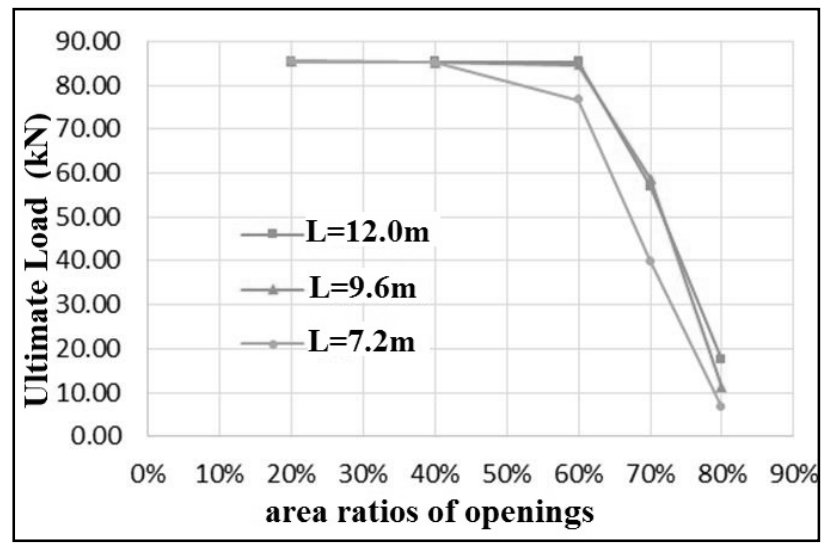

values is $200 \mathrm{~mm}$ to $400 \mathrm{~mm}$.

Fig.3. Ultimate load curves

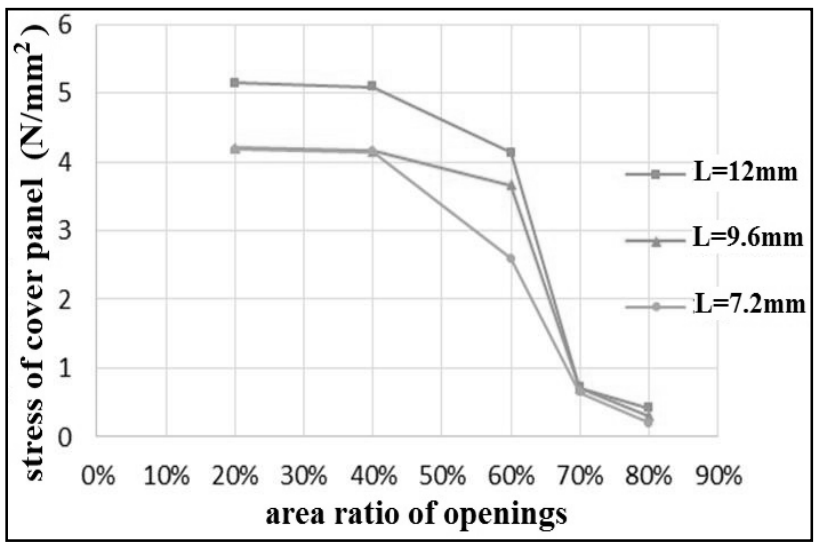

Fig.4. Stress of cover panel curves

Change the area ratio of openings in light frame shear wall, creating models of nonlinear parameter analysis to find the influence of changing parameters of area ratio of openings on lateral resistant performance of light frame shear wall. The area ratios of openings in light frame shear wall are 20, 40, 60, 70, 80 percent, respectively.

From the simulation result (figure.3 and figure.4), both ultimate load of light frame shear wall and stress of cover panel decreased with area ratio of openings increase and inclined to negative relationships. With the area ratio of openings inflation at 60 percent, the load of light frame shear wall and stress of cover panel show a sharp decline. So the area ratio of openings should be no more than 60 percent in the design of light frame shear wall.

The height-width ratio of wall panel is fairly large in value caused by openings of wall in the design of light wood frame construction. The more height-width ratio of wall panel increases, the more obvious bending deformation of wall panel, and it will do a great harm to the mechanical property and ateral deformation capacity of light wood frame construction. Aiming at the light frame shear wall with opening, six nonlinear parameter analysis models are established to determine the impact of height-width ratio of wall panel on mechanical properties of light frame shear wall.

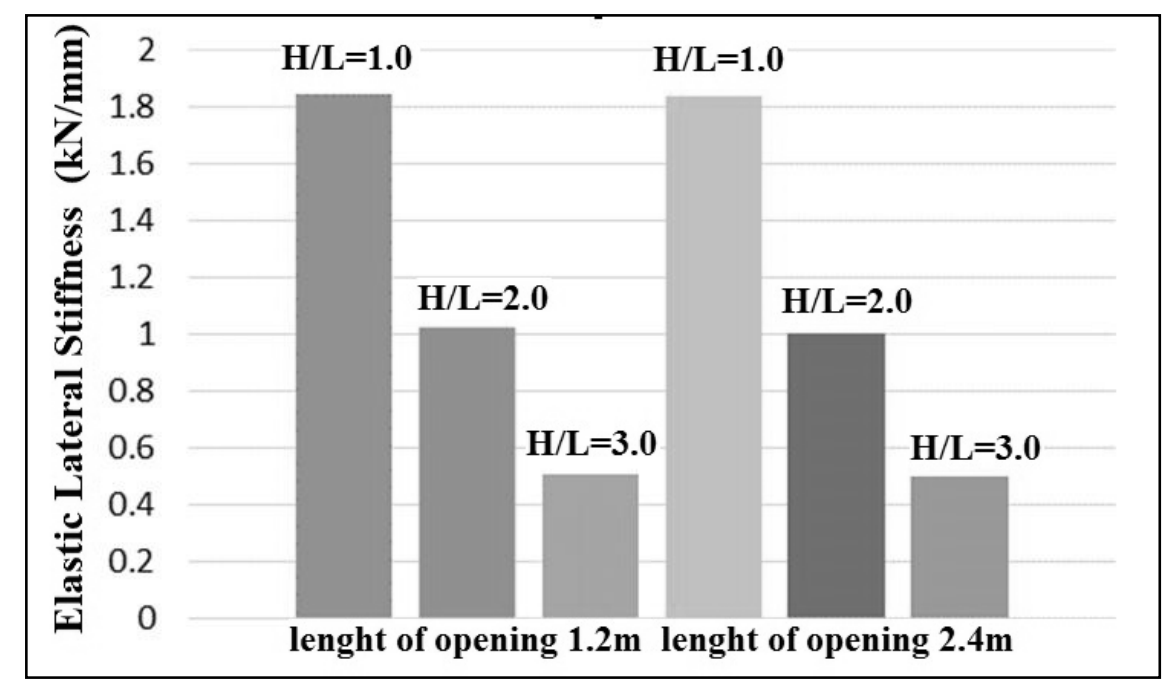

Fig.5. Elastic lateral stiffness

In the results, define the lateral stiffness when story drift value is $\mathrm{H} / 250$ as elastic lateral stiffness. From the figure.5, we can find that the elastic lateral stiffness of light frame shear wall is usually proportion to effective length of wall. The results show that with the reduction of height-width ratio $(\mathrm{H} / \mathrm{L})$ of wall panel, the elastic lateral stiffness getting smaller. The conclusions described above are superficially similar to those reached by previous studies. 


\section{Conclusion}

Based on the nonlinear parameter analysis of light frame shear wall, the main influence factors in lateral resistant performance of the light frame shear wall are found in this research, including studs spacing, height-width ratio of wall, the size and position of the openings. In addition, some design suggestions of light frame shear wall are put forward, concluded as follows: 1 . The range of values for studs spacing is $400 \mathrm{~mm}$ to $600 \mathrm{~mm}$ when height-width ratio is less than 0.4 , otherwise the range of values is $200 \mathrm{~mm}$ to $400 \mathrm{~mm}, 2$. The height-width ratio of wall should be limit (no more than 1.0 ), 3 . The area ratio of openings should be no more than 60 percent in the design of light frame shear wall.

\section{Acknowledgements}

This work was financially supported by Guizhou Province Science and Technology Foundation (QianKeHe J [2010] 2246).

\section{References}

[1] Wood Design Manual.2005: Canada Wood Council.

[2] Blasetti, A.S, Hoffman, R.M, Dinehart, D.W. Simplified hysteretic finite-element model for wood and viscoelastic polymer connections for the dynamic analysis of shear walls. J. Struct. Eng., 2008, v 134, 77-86.

[3] Doudak, G, Smith, I, McClure, G, Mohammad, M, Lepper, P. Tests and finite element models of wood light-frame shear walls with openings. J. Struct. Eng. and Mat., 2006, 8(4), 165-174.

[4] Yaohua Qian. The finite element analysis of wood frame shear walls. D .Yangzhou University, 2012.

[5] Judd J.P. Finite Element Analysis of Wood Shear Walls and Diaphragms Using ABAQUS. ABAQUS Users Conference, 2002.

[6] Jian Xu, J. Daniel Dolan, F.ASCE, Development of a Wood-Frame Shear Wall Model in ABAQUS. J. Struct. Eng.2009, 978-984.

[7] Jian Xu, J. Daniel Dolan, F.ASCE, Development of a Wood-Frame Shear Wall Model in ABAQUS. J. Struct. Eng.2009, 978-984. 